\title{
obituaries
}

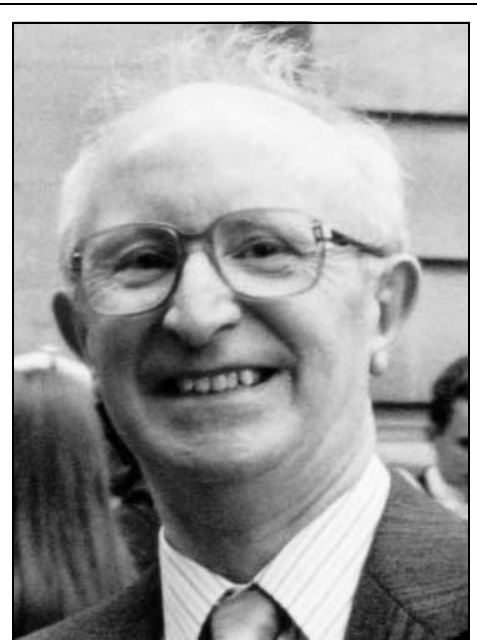

Albert West

Former Consultant Psychiatrist St Crispin Hospital, Northampton

Albert West died suddenly on 20 August 2001. After qualifying MBChB (1958) in Birmingham he trained in psychiatry in Manchester under Professor E. W. Anderson. In the early 1960s the Manchester School was noted for a phenomenological approach that left Albert confident and well qualified to practise as a consultant when he was eventually appointed to St Crispin in 1972 He was soon in charge of the centralised day centre and later directed the intensive treatment unit and the forensic assessment unit. He obtained the DPM in 1965, the MRCPsych in 1971 and was later elected to the Fellowship in 1985

He was appreciated as a patient and thoughtful teacher and his calm and courteous manner and his popularity with his colleagues soon resulted in many administrative posts and the chairing of committees. A wicked sense of humour (his humorous tales of everyday mishaps, mostly against himself, brightened his colleagues' days) was underpinned by a firm religious conviction that inevitably coloured his everyday work. Above all, Albert helped people, both his patients and friends who had problems and needed advice.

He had a special interest in forensic psychiatry and following his retirement from the NHS in 1994 he continued with medico-legal work and as an adroit member of mental health review tribunals. In that work he relished exercising his logical mind and he approached this task without fear or favour.

His interests were photography and reading, but much of his free time was spent on church work. His valued friendship will be missed by many. He is survived by his wife, Margaret, and his son, Stephen.

George Hay

\section{Dr John David Waite Fisher}

Former Consultant Psychiatrist Ticehurst House Hospital

Wadhurst, East Sussex

John Fisher - David to his friends, family and colleagues - died on 3 December 2000 after a year's illness. To me he was the backbone of the psychiatric services in North Kent, the font of psychiatric wisdom as well as plain commonsense, for David was a plain, good man. From his childhood his health was never robust. Rather than a sporting school, his family sent him to Bootham Quaker School in York, where his exposure to the Quaker meeting may have expanded into his later interest in therapeutic communities. The family business was in the Bradford woo trade, and after school both he and his brother seemed destined for a Priestleyan life, but witnessing his father in a typically outspoken business meeting with a colleague convinced David that his interests lay elsewhere. His first love was in nature and he astounded his family with the choice of a degree course in agriculture at Clare College, Cambridge. A delightful postgraduate year followed his MA, spent on 'field research' in the fens and pubs of rural Cambridgeshire. Then came the sort of incident that changes the course of one's life. Plagued by sinusitis, at 23 he was operated on with nearly fatal results, and this convinced David to devote himself to medicine. He continued at Cambridge, now in medical studies, and graduated MBBS (1957) and elected FRCP (Edinburgh) in 1975. Health intervened again at this stage: his longstanding eczema was so severe and visible that David eschewed a 'hands-on' speciality.

After his house jobs, David went straight to a psychiatric post in Aberdeen and then at the Royal Edinburgh Hospital on one of the earliest rotational training schemes. David's career spans many important post-war developments in British psychiatry. He passed his MRCPsych in 1971 and elected FRCPsych in 1974. He was in charge of long-stay and psychogeriatric wards, he ran an early sector service in Surrey and he reorganised a rehabilitation unit on therapeutic community lines. He was a senior registrar at the Middlesex Hospital, became a consultant at Warlingham Park Hospital and psychiatric adviser to the London Borough of Croydon. In Croydon he ran the new day hospital and was the psychiatrist working with the newly formed community psychiatric nursing service. In 1976 David moved to North Kent, as consultant at Oakwood Hospital, being one of the two consultants in the psychiatric service of the Medway Towns, which had always been semi-independent

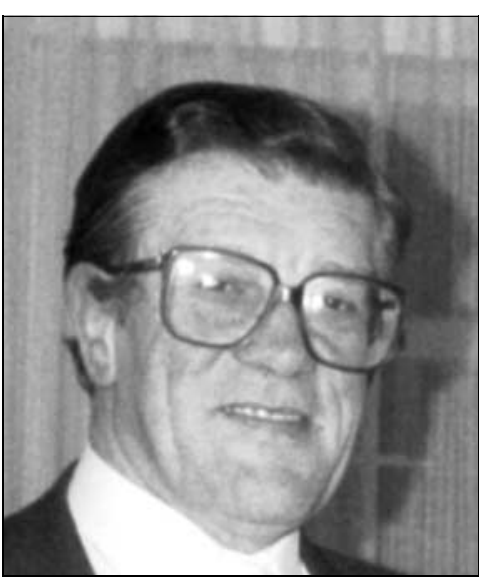

of the local mental hospital. David's view was that the consultant should, in the main, stay out of the hospital, within his/her community. Long associated with teaching, he held one of the early honorary academic posts at Guy's Hospital, and was instrumental in persuading London medical students to peripheral attachments, which they came to hold in high regard. He was an energetic member of College educational committees. As Clinical Tutor at Oakwood Hospital, David started the rotational training scheme, which became one of the largest rotations in the south-east. As medical manager, he was a good negotiator, who brought a bluff Yorkshire commonsense to the arcane world of mental health services, but underneath was the keen brain of someone who knew where he was going. David was an excellent clinician, balanced and thorough. His relaxed manner in the ward round, with his shoes off for comfort, was loved and caricatured by his team. Since his death, tributes have poured in from the mental health review tribunals and the Mental Health Act Commission, where he was a popular medical member. David was a sociable man, a bon viveur who loved to travel the world with his wife, Pat. The beautiful garden of their cottage was the object of his devotion and the expert agricultural knowledge from his early years. A lifelong friend and colleague said that David is an easy subject for a eulogy; a gentle, kind man who gave his all for his work, his patients and his family.

\section{R. L. Symonds}

\section{Arnold StanleyThorley}

Former Consultant Psychiatrist Belmont Hospital, Sutton, Surrey

Arnold Thorley died on 27 March 2001 at the age of 94 . He was born on 7 January 1907. He studied medicine at University College Hospital, London, and qualified 